\title{
Green vs. Green: \\ Measuring the Compensation Required to Site \\ Electrical Generation Windmills in a Viewshed
}

\author{
Peter A. Groothuis \\ Department of Economics \\ Appalachian State University \\ Boone, NC 28608 \\ Jana D. Groothuis \\ Boone, NC 28608 \\ and \\ John C. Whitehead \\ Department of Economics \\ Appalachian State University \\ Boone, NC 28608
}

June 2007 
ABSTRACT: A willingness to accept framework is used to measure the compensation required to allow wind generation windmills to be built in the mountains of North Carolina. We address why the NIMBY syndrome may arise when choosing site locations, the perceived property rights of view-sheds, as well as the perceptions of the status quo in the southern Appalachian Mountains. We find that individuals who perceive wind energy as a clean source of power require less compensation. Those who retire to the mountains or individuals who have ancestors from Watauga County require more compensation to accept windmills in their view-shed. We find that annual compensation is about twenty three dollars per household. In the aggregate, citizens need to be compensated by about one-half million dollars a year to allow wind electrical generation turbines in Watauga County. In addition, we find in a bivariate-probit analysis that individuals who are more likely to participate in a green energy program also are more likely to allow electrical generation wind mills in their view-shed suggesting that the green on green environmental debate is overstated. 


\section{Introduction}

Wind electrical generation is becoming an economically viable technique.

Proponents say that wind power is both a green and sustainable energy source. Green energy is defined as a source that does not contribute to global warming or other negative externalities such as acid rain or decreased visibility (Kahn 2003). Borchers et al (2007) using a choice experiment find that consumers are willing to pay more for green energy including wind, solar and biomass relative to conventional sources. Whitehead and Cherry (forthcoming) using the contingent valuation method suggest that individuals are willing to pay a premium to purchase green energy knowing that their choice leads to a cleaner environment. Roe et al. (2001) using the hedonic study find consumers are willing to pay a premium for renewable energy sources.

Those who oppose wind energy, however, point out that wind generation turbines can cause local negative externalities. Individuals who live near wind generation turbines have reported negative visual impact on the landscape, noise from the rotation of windmill blades and shadow and light effects from the windmills (Warren et al. 2005). Landenburg and Dubgaard (2007) find that individuals are willing to pay higher electrical bills to site coastal wind farms further from the coast. The two sides to this wind power debate have been labeled by some as a green on green environmental debate. Proponents focus on the clean air and opponents focus on the local negative externalities (Warren et al. 2005). One recent example of the green on green debate is the Cape Cod coastal wind farms where a slim majority of respondents were opposed to wind farms (Coleman and Melo. 2004). Other examples are detailed in Pasqualetti (2004) where individuals argue that pristine landscapes will be damaged by windmills. 
Local negative externalities from wind turbines fall into the broad problem known as a locally undesirable land use, or LULU. In turn, LULUs lead to the NIMBY (not in my backyard) syndrome. Economists theorize that the NIMBY syndrome leads to inefficient allocation of resources because the external costs of a LULU are borne locally by the neighborhood surrounding the facility, while the benefits are distributed globally throughout the economy (O'Hare 1977, Kunreuther et al 1987). To address the problem of inefficiency and to encourage the placement of a LULU, those that receive the benefits could compensate the neighborhood around the site for bearing the external cost (O'Hare 1977 and Kunreuther et al 1987).

To gain understanding of citizen's perceptions of wind power and their influence on mountain views we developed a contingent valuation (CV) survey. The CV analysis provides insights on how to overcome the NIMBY syndrome by eliciting the willingness to accept (WTA) for changes in the county's view-shed amenities of wind turbines. Although the willingness to pay framework is the preferred question format in CV analysis, the WTA framework is more appropriate given the perceived property rights of individuals in the current context. Individuals perceive that the status quo defines property rights, making the WTA the appropriate measure. CV analysis has been used successfully in the past to measure the WTA (See Groothuis, Van Houtven, and Whitehead 1998, and Carson, Flores and Meade 2001).

The survey was sent to Watauga County, North Carolina, residents. This County, located in the southern Appalachian highlands, offers an interesting case study because it has been identified as a potential wind farm location and is also noted for its scenic views 
(Grady 2002). The Blue Ridge Parkway runs through the county. Many vacation homes are built in the area and tourism is a major industry. Watauga County also has had decreased visibility due to coal powered electrical generation plants and would benefit from the green energy that wind power would provide (Grady 2002).

\section{Section 1: Survey Methodology and Results}

The survey was mailed in the spring of 2005 to a random sample of 1200 Watauga County residents. We used a primary mailing, a post card reminder and a second mailing to all non-respondents of the first wave. In the end, we had 901 useable addresses and 389 responses giving us a response rate of 43 percent. In table 1, we provide a summary of the demographic variables. The average age of our respondent was 55.7 years, while the average age for the county of all residents over 20 was 43.5 . The average income of survey respondents was $\$ 61,084^{1}$ while the average income in Watauga County from the 2000 census was $\$ 50,300$ in 2005 dollars. The average level of education for the respondents was 15 years and for the county it was 14 years. The respondents are older, slightly more educated and have higher income than the population. In addition eleven percent of the respondents have retired to Watauga County and 33 percent report having ancestors who lived in Watauga County.

In order to compare respondent attitudes, in tables, 2, 3 and 4, we summarize the opinions of the usefulness and impact on mountain views of various technologies that could cause externalities. These include cell phone towers, billboards and electrical generation wind mills. We find that 46 percent of respondents find that billboards provide somewhat useful information and 42 percent use billboards to make decisions on 
where to shop and eat when they visit other locations. Yet around 80 percent either find that billboards are somewhat harmful to very harmful to the mountain views of Watauga County.

When it comes to cell phone towers, the vast majority, $91 \%$, find that the cell phone service is somewhat useful to very useful. Yet, $67 \%$ feel that cell towers are somewhat harmful to very harmful to mountain views. A majority of respondents also feel that wind energy is a clean energy that should be pursued. Yet, $64 \%$ feel that electrical generation wind mills will harm mountain views. This series of tables show respondents find that billboards, cell phone towers, and wind electrical power all provide benefits. They also feel that they all harm mountain-view amenities, suggesting that tradeoffs need to be made.

\section{Section 2: Participation in Green Energy Programs}

Wind energy provides benefits to citizens of the Appalachian Mountains. To help understand who receives the benefits, we ask about participation in a Green energy program. In the survey the following statement was included:

A Green Energy proposal has been implemented in North Carolina. Green Energy offers customers power generated from renewable sources such as wind or solar power at a higher price than electricity generated with coal or oil. Green energy reduces air pollution in the mountains and improves visibility. Do you participate or plan to participate in the Green Energy program in North Carolina? YES or NO

We find that $35.8 \%$ of respondents report that they participate or plan to participate in the green energy program. To further explore who participates, a logit analysis is used to determine the willingness to participate in the green energy program. Reported in table 5, we find that older individuals are less likely to participate than 
younger individuals. We also show that individuals who report ancestors who lived in Watauga County are less likely to participate in a green energy program than individuals who did not have ancestors who lived in Watauga County. In terms of the attitudinal variables, we find that individuals who strongly agree or agree that wind power is clean and should be pursued were more likely to participate in the green energy program. The coefficient on the variables Wind-power-is-harmful-to-mountain-views and Windenergy-should-be-allowed-in-Watauga County are both statistically insignificant. The results suggest that some individuals in Watauga County are willing to pay more to receive the global benefits of green power.

\section{Section 3: Willingness to Accept for Electrical Generation Windmills}

Wind energy creates negative externalities for citizens of the Appalachian Mountains when the wind mills are built in the view-shed. We analyze a CV question to provide insight on how to overcome the NIMBY syndrome by providing compensation to the affected parties. Using this technique we can elicit the willingness to accept (WTA) for changes in the county's view-shed amenities from wind turbines.

Theory:

Consider a resident's utility function who receives utility from both a consumption good, $\mathrm{z}$ and a scenic view amenity, $\mathrm{x}(\mathrm{q})$, where $\mathrm{q}$ represents quality of the scenic amenity that can be affected by the presence of windmills. Then a resident maximizes her utility, $\mathrm{u}(\mathrm{x}(\mathrm{q}), \mathrm{z})$, subject to a budget constraint $\mathrm{y}=\mathrm{px}+\mathrm{z}$ where the price of $\mathrm{z}$ is normalized to one. Solving for the indirect utility function yields $v(p, y, q)$ where $p$ 
represents the price of the scenic amenity and $y$ is income. The willingness-to-accept, WTA, for lowering the quality of a scenic view amenity is found when,

$$
\text { 1) } v\left(p^{0}, q^{0}, y\right)=v\left(p^{0}, q^{1} y+\text { WTA }\right) \text {, }
$$

where $\mathrm{p}^{0}$ is the current price, $\mathrm{q}^{1}$ is lowered quality and WTA is the willingness-to-accept compensating variation for lowering scenic view quality.

In our case the $\mathrm{CV}$ question for the windmill proposal is:

Suppose, to generate Green electricity, windmill generators are to be built on four ridge tops throughout Watauga County. To compensate individuals in the county for accepting windmills, electric utility bills would be reduced by $\$$ A each month per household. Suppose that this proposal, approving the electrical payment reduction and allowing electrical windmills to be built, is on the next election ballot. How would you vote on this proposal?

\section{FOR AGAINST DON'T KNOW}

One problem that arises when estimating dichotomous choice CV questions is what to do with Don't Know responses. We follow the status quo approach and code all Don't Know responses as "No" responses (Caudill and Groothuis 2004 and Groothuis and Whitehead 2002). This becomes our variable that we label Yes.

In table 6, we report the percentage of votes by offer. We find for the lowest offer of one dollar per month, only $42 \%$ would vote for the proposal but increasing the offer to $\$ 2.50$ per month 53\% were in favor of the wind proposal. For higher offer levels of $\$ 5.00, \$ 10.00$ and $\$ 50.00$ over 60 percent would vote for the wind proposal. In Table 7 column 1, we report the results of two specifications on the wind proposal.

2) $\mathrm{P}($ Yes $)=\beta_{0}+\beta_{1} \log (\mathrm{A})+\beta_{2}$ Income $+\varepsilon_{2}$

3) $\mathrm{P}($ Yes $)=\beta_{0}+\beta_{1} \log (\mathrm{A})+\beta_{2}$ Income $+\beta_{3}$ Education $+\beta_{4}$ Age $+\beta_{5}$ Clean +

$\beta_{6}$ Harm $+\beta_{7}$ Allowed $+\beta_{8}$ Ancestor $+\beta_{9}$ Retire $+\varepsilon_{2}$ 
In both specifications as the log of payment $\mathbf{A}$ increases respondents are more likely to be in favor of the proposal. In the first specification, the coefficient on the income variable is found to be negative and statistically significant, indicating that landscape is a normal good. In the second specification all three attitudinal variables are found to have statistically significant coefficients. Individuals who find wind power a clean source of power that should be pursued are more likely to vote for the proposal. Individuals who find wind power harmful to mountain views are less likely to say yes. Also individuals who believe wind power should be allowed are more likely to vote in favor of the proposal. Individuals who retire to Watauga County are less likely to say yes, while individuals with ancestors in the county are also less likely to say yes to the proposal. In the second specification, we find that age, education and income are all have statistically insignificant coefficients. These results point to compensation playing a role in solving the NIMBY syndrome.

Using the Cameron and James (1987) technique we can calculate the median WTA using:

$$
\begin{aligned}
& \text { 4) } \mathrm{WTA}=\exp \left(\left(\beta_{0}+\beta_{2} \text { Income }+\beta_{3} \text { Education }+\beta_{4} \text { Age }+\beta_{5} \text { Clean }+\right.\right. \\
& \left.\left.\beta_{6} \text { Harm }+\beta_{7} \text { Allowed }+\beta_{8} \text { Ancestor }+\beta_{9} \text { Retire }\right) / \beta_{1}\right) .
\end{aligned}
$$

We find that in the WTA is $\$ 1.90$ per month or a compensation of $\$ 23$ per household per year.

To further explore the green on green environmental debate, where individuals focus on either the positive benefits or the local negative externalities of wind power, we analyze a bivariate-probit analysis of both the willingness to participate in a Green Energy program and the willingness to accept windmills in Watauga County. In table 8, 
the results mirror those of both univariate analyses. The interesting result is that the rho ( $\rho$ ) coefficient that measures the unobserved correlation between the two equations is positive and statistically significant. Individuals who respond yes to the green-energy participation equation are also more likely to respond yes to the willingness to accept windmills equation. This result indicates that the green on green conflict does not necessarily arise in the same individual. Instead, individuals who are willing to pay more for green energy are also more likely to allow windmills into their view-shed. This runs counter to the conventional wisdom that individuals who are concerned with the environment are willing to pay for clean air as long as the wind energy is not produced in their view-shed. On the contrary, individuals who are willing to pay more for green energy require less compensation to site windmills in their backyard.

\section{Section 5: Conclusions}

Our results indicate that compensation could play a role to help eliminate the NIMBY syndrome when choosing sites for electrical generation windmills. We also find that individuals who are willing to participate in green energy programs require less compensation than individuals who do not participate. This result suggests that the green on green environmental debate is overstated. In addition, we show that individuals who retire to the mountains require more compensation as do individuals who have ancestors in the county. The landscape is important to citizens of Watauga County but they are willing to make trade offs to allow for wind power.

To gain an understanding of the total compensation required to site wind turbines in Watauga County, we can aggregate the household results of 23 dollars annually. Using the 2000 census we find that there are 18,540 households in Watauga County 
giving an aggregate WTA of $\$ 426,400$ dollars per year. This estimate can be thought as the amount that would be approved in a referendum election -- reflecting the preferences of a median voter. Thus it would be the amount required to eliminate the NIMBY syndrome and site wind turbines. 


\section{$\underline{\text { References }}$}

Borchers, Allison M., Joshua M. Duke and George R. Parsons, "Does Willingness to Pay for Green Energy Differ by Source?” Energy Policy, 35, 3327-3334, 2007.

Cameron, Trudy Ann and Michele James, "Efficient Estimation Methods for 'Closed Ended' Contingent Valuation Surveys," Review of Economics and Statistics, 69, 269-276, 1987.

Carson, Richard T., Nicholas E. Flores and Norman F. Meade, 'Contingent Valuation: Controversies and Evidence', Environmental and Resource Economics 19, 1732102001.

Caudill, Steve B. and Peter A. Groothuis, "Modeling Hidden Alternatives in random Utility Models: An Application to "Don't Know" Responses in Contingent Valuation," Land Economics 81, 2005, pp. 445-454.

Coleman, J., and F. Melo, Poll: Slim majority opposes wind farm. Cape Cod Times, March 4, 2004.

Grady, Dennis O. "Public Attitudes Toward Wind Energy in Western North Carolina: A Systematic Survey" The 2002 NC Wind Summit Boone NC, December 2002.

Groothuis, Peter A., G. Van Houtven, John C. Whitehead. "Using Contingent Valuation to Measure the Compensation Required to Gain Community Acceptance of a LULU: The Case of a Hazardous Waste Disposal Facility." Public Finance Review 26:31998.

Groothuis, Peter A., and John C. Whitehead, "Does Don't Know Mean No? Analysis of 'Don't Know Responses in Dichotomous Choice Contingent Valuation Questions," Applied Economics, 34, 1935-1940, 2002.

Kahn, Robert D. "Siting Struggles: The Unique Challeng of Permitting Renewable Energy Power Plants" The Electricity Journal, 21-33, March 2000.

Kunreuther, Howard, Paul Kleindofer and Peter J. Knez. "A Compensation Mechanism for Siting Noxious Facilities: Theory and Experimental Design," Journal of Environmental Economics and Management, 14, 371-383 1987.

Ladenburg Jacob and Alex Dubgaard "Willingness to Pay for Reduced Visual Disamenities from Off-Shore Windfarms in Denmark" Energy Policy 4059-4071 2007.

O'Hare, Micheal "'Not on my Block You Don't': Facility Siting and the Strategic Importance of Compensation, Public Policy 25:4, 407-58 1977. 
Pasqualetti, Martin J. "Wind power: obstacles and opportunitie" Environment, Sept, 2004

Roe, Brian, Mario F. Teisl, Alan Levy, and Matthew Russell, "U.S. Consumers' Willingness to Pay for Green Electricity” Energy Policy 29 917-925 2001.

Warren, Charles R., Carolyn Lumsden, Simone O'Dowd, and Richard V. Birnie 'Green On Green': Public perceptions of wind power in Scotland and Ireland" Journal of Environmental Planning and Management 486 November 853 - 8752005.

Whitehead, John C., "Item Nonresponse Bias in Contingent Valuation: Should CV Researchers Impute Values for Missing Independent Variables?" Journal of Leisure Research, 26, 296-303, 1994.

Whitehead, John C., and Todd L. Cherry, "Mitigating the Hypothetical Bias of Willingness to Pay: A Comparison of Ex-Ante and Ex-Post Approaches," Department of Economics Working Paper \#04-21, Boone, NC: Appalachian State University, 2004. 
Table 1 Means of Variables

\begin{tabular}{|l|l|}
\hline Variable & Mean \\
\hline Age & $\begin{array}{l}55.7 \text { years } \\
(16.0)\end{array}$ \\
\hline Income & $\begin{array}{l}\$ 61,084 \\
(33.97)\end{array}$ \\
\hline Education & $\begin{array}{l}15.09 \text { years } \\
(3.81)\end{array}$ \\
\hline $\begin{array}{l}\text { Wind powers should be } \\
\text { allowed in Watauga } \\
\text { County }\end{array}$ & $\begin{array}{l}.61 \\
(.48)\end{array}$ \\
\hline $\begin{array}{l}\text { Ancestor from Watauga } \\
\text { County }\end{array}$ & $\begin{array}{l}.33 \\
(.47)\end{array}$ \\
\hline Retire to Watauga & .16 \\
& $(.37)$ \\
\hline
\end{tabular}

(Standard deviation in parentheses)

${ }^{1}$ Electical generation wind mills should be allowed in Watauga County.

Strongly Agree or Agree equal one

Strongly Disagree or Disagree equal zero

$\mathrm{n}=337$ 
Table 2: Opinions about Billboards

\begin{tabular}{|c|c|c|c|c|c|}
\hline & 1 & 2 & 3 & 4 & 5 \\
\hline $\begin{array}{l}\text { Do you feel billboards } \\
\text { provide useful information } \\
\text { to tourists and residents? }\end{array}$ & $\begin{array}{l}\text { Not At All } \\
\text { Useful } \\
14.9 \%\end{array}$ & $22.5 \%$ & $\begin{array}{l}\text { Somewhat } \\
\text { Useful } \\
46.3 \%\end{array}$ & $7.8 \%$ & $\begin{array}{l}\text { Very Useful } \\
8.3 \% \\
\end{array}$ \\
\hline $\begin{array}{l}\text { Do you feel that billboards } \\
\text { are harmful to mountain } \\
\text { views? }\end{array}$ & $\begin{array}{l}\text { Not at all } \\
\text { Harmful } \\
9.4 \%\end{array}$ & $8.9 \%$ & $\begin{array}{l}\text { Somewhat } \\
\text { Harmful } \\
32.5 \%\end{array}$ & $18.3 \%$ & $\begin{array}{l}\text { Very } \\
\text { Harmful } \\
30.9 \%\end{array}$ \\
\hline $\begin{array}{l}\text { Do you use billboards to } \\
\text { make decisions on where } \\
\text { to shop and eat when you } \\
\text { visit other locations? }\end{array}$ & $\begin{array}{l}\text { Never } \\
27.2 \%\end{array}$ & $16.2 \%$ & $\begin{array}{l}\text { Some of the } \\
\text { Time } \\
42.4 \%\end{array}$ & $6.8 \%$ & $\begin{array}{l}\text { All the time } \\
7.3 \%\end{array}$ \\
\hline
\end{tabular}

Table 3: Opinions about Cell Phone Towers

\begin{tabular}{|c|c|c|c|c|c|}
\hline (2) & 1 & 2 & 3 & 4 & 5 \\
\hline $\begin{array}{l}\text { Do you feel cell phone } \\
\text { coverage provides useful } \\
\text { service for cell phone } \\
\text { owners such as } \\
\text { convenience and safety? }\end{array}$ & $\begin{array}{l}\text { Not At All } \\
\text { Useful } \\
2.5 \%\end{array}$ & $6.3 \%$ & $\begin{array}{l}\text { Somewhat } \\
\text { Useful } \\
24.4 \%\end{array}$ & $25.2 \%$ & Very Useful \\
\hline $\begin{array}{l}\text { Do you feel that cell phone } \\
\text { towers are harmful to the } \\
\text { mountain views? }\end{array}$ & $\begin{array}{l}\text { Not at all } \\
\text { Harmful } \\
13.4 \%\end{array}$ & $18.9 \%$ & $\begin{array}{l}\text { Somewhat } \\
\text { Harmful } \\
39.7 \%\end{array}$ & $16.1 \%$ & $\begin{array}{l}\text { Very } \\
\text { Harmful } \\
11.7 \%\end{array}$ \\
\hline
\end{tabular}

Table 4: Opinions about Electrical Generation Wind Mills

\begin{tabular}{|c|c|c|c|c|c|}
\hline & 1 & 2 & 3 & 4 & 5 \\
\hline $\begin{array}{l}\text { Do you feel electrical that } \\
\text { generation wind mills are a } \\
\text { clean energy source that } \\
\text { should be pursued in the } \\
\text { future? }\end{array}$ & $\begin{array}{l}\text { Should Not } \\
\text { Be Pursued } \\
5.8 \%\end{array}$ & $5.8 \%$ & $22.5 \%$ & $18.1 \%$ & $\begin{array}{l}\text { Should Be } \\
\text { Pursued } \\
48.0 \%\end{array}$ \\
\hline $\begin{array}{l}\text { Do you feel that electrical } \\
\text { generation wind mills are } \\
\text { harmful to the mountain } \\
\text { views? }\end{array}$ & $\begin{array}{l}\text { Not at all } \\
\text { Harmful } \\
15.1 \%\end{array}$ & $20.8 \%$ & $\begin{array}{l}\text { Somewhat } \\
\text { Harmful } \\
42.2 \%\end{array}$ & $12.6 \%$ & $\begin{array}{l}\text { Very } \\
\text { Harmful } \\
9.3 \%\end{array}$ \\
\hline
\end{tabular}


Table 5: Determinants of Willingness to Participate in Green Energy Program

\begin{tabular}{|c|c|}
\hline Variable & Participate \\
\hline Intercept & $\begin{array}{l}-1.14 \\
(1.04)\end{array}$ \\
\hline Income & $\begin{array}{l}.001 \\
(0.33)\end{array}$ \\
\hline Education & $\begin{array}{l}-.103 \\
(0.26)\end{array}$ \\
\hline Age & $\begin{array}{l}-.357^{* *} \\
(3.44)\end{array}$ \\
\hline $\begin{array}{l}\text { Wind power is clean and } \\
\text { should be pursued }\end{array}$ & $\begin{array}{l}.810^{* *} \\
(4.66)\end{array}$ \\
\hline $\begin{array}{l}\text { Wind power harmful to } \\
\text { mountain views }\end{array}$ & $\begin{array}{l}-.040 \\
(0.29)\end{array}$ \\
\hline $\begin{array}{l}\text { Wind power should be } \\
\text { allowed in Watauga County }\end{array}$ & $\begin{array}{l}-.073 \\
(0.12)\end{array}$ \\
\hline Ancestor in Watauga & $\begin{array}{l}-1.11^{* *} \\
(3.48)\end{array}$ \\
\hline Retired to Watauga & $\begin{array}{l}.075 \\
(0.09)\end{array}$ \\
\hline$\chi^{2}$ & $149.21 * *$ \\
\hline
\end{tabular}


Table 6: Percentage of respondents votes of wind proposal by offer

\begin{tabular}{|l|l|l|l|}
\hline Offer & Yes & no & Total \\
\hline$\$ 1.00$ & $42 \%$ & $58 \%$ & 78 \\
\hline$\$ 2.50$ & $53 \%$ & $47 \%$ & 64 \\
\hline$\$ 5.00$ & $65 \%$ & $35 \%$ & 73 \\
\hline$\$ 10.00$ & $67 \%$ & $33 \%$ & 64 \\
\hline$\$ 50.00$ & $67 \%$ & $33 \%$ & 48 \\
\hline
\end{tabular}


Table 7: Determinants of Willingness to Accept Electrical Windmills

\begin{tabular}{|c|c|c|}
\hline Variable & Yes & Yes \\
\hline Intercept & $\begin{array}{l}0.56^{*} \\
(1.77)\end{array}$ & $\begin{array}{l}-1.93 \\
(1.73)\end{array}$ \\
\hline $\begin{array}{l}\text { Log of Electrical Bill } \\
\text { Reduction }\end{array}$ & $\begin{array}{l}.224 * * \\
(3.65)\end{array}$ & $\begin{array}{l}.448 * * \\
(3.65)\end{array}$ \\
\hline Income & $\begin{array}{l}-.0067^{*} \\
(1.86)\end{array}$ & $\begin{array}{l}-.0064 \\
(1.31)\end{array}$ \\
\hline Education & & $\begin{array}{l}-.103 \\
(0.25)\end{array}$ \\
\hline Age & & $\begin{array}{l}-.165 \\
(0.17)\end{array}$ \\
\hline $\begin{array}{l}\text { Wind power is clean and } \\
\text { should be pursued }\end{array}$ & & $\begin{array}{l}.635^{* *} \\
(4.30)\end{array}$ \\
\hline $\begin{array}{l}\text { Wind power harmful to } \\
\text { mountain views }\end{array}$ & & $\begin{array}{l}-.289 * * \\
(2.18)\end{array}$ \\
\hline $\begin{array}{l}\text { Wind power should be } \\
\text { allowed in Watauga County }\end{array}$ & & $\begin{array}{l}1.60 * * \\
(5.00)\end{array}$ \\
\hline Ancestor in Watauga & & $\begin{array}{l}-.944 * * \\
(2.82)\end{array}$ \\
\hline Retired to Watauga & & $\begin{array}{l}-.947 * * \\
(2.20)\end{array}$ \\
\hline Log likelihood Ratio & & $153.81 * *$ \\
\hline $\begin{array}{l}\text { Median WTA } \\
\text { (95\% Confidence Interval) }\end{array}$ & & $\begin{array}{l}\$ 1.90 \\
(\$ .50 \text { to } \$ 3.30)\end{array}$ \\
\hline
\end{tabular}

${ }^{*}$ statistically significant at $90 \%$ level. ${ }^{* *}$ statistically significant at $95 \%$ level 
Table 8: Bivarite Probit: Willingness to Accept Electrical Windmills and Willingness to Participate to Participate in Green Energy Program

\begin{tabular}{|l|l|l|}
\hline Variable & $\begin{array}{l}\text { Yes } \\
\text { Accept Windmills }\end{array}$ & $\begin{array}{l}\text { Yes } \\
\text { Participate Green Energy }\end{array}$ \\
\hline Intercept & -1.081 & -.710 \\
$(1.67)$ & $(1.16)$ \\
\hline $\begin{array}{l}\text { Log of Electrical Bill } \\
\text { Reduction }\end{array}$ & $0.254^{*}$ & --- \\
\hline Income & $(3.74)$ & \\
\hline Education & -.003 & .001 \\
& $(1.26)$ & $(0.32)$ \\
\hline Age & -.006 & -.166 \\
& $(0.25)$ & $(0.71)$ \\
\hline $\begin{array}{l}\text { Wind power is clean and } \\
\text { should be pursued }\end{array}$ & -.001 & $-.020^{*}$ \\
& $(0.12)$ & $(3.76)$ \\
\hline $\begin{array}{l}\text { Wind power harmful to } \\
\text { mountain views }\end{array}$ & $(4.38)$ & $.421^{*}$ \\
& $-.169^{*}$ & $(4.72)$ \\
\hline $\begin{array}{l}\text { Wind power should be } \\
\text { allowed in Watauga County }\end{array}$ & $(2.44)$ & .030 \\
& $.984^{*}$ & $(0.39)$ \\
\hline Ancestor in Watauga & $-.558^{*}$ & .051 \\
& $(2.76)$ & $(0.26)$ \\
\hline Retired to Watauga & $-.583^{*}$ & $-.653^{*}$ \\
& $(2.27)$ & $(3.44)$ \\
\hline Rho & $.406^{*}$ & .005 \\
& $(3.70)$ & $(0.02)$ \\
\hline Log likelihood Ratio & $-331.56^{*}$ & \\
\hline
\end{tabular}

*statistically significant at $95 \%$ level. 

${ }^{1}$ Income tends to have the most item non-response of all demographic questions. Following Whitehead
(1994) we impute 18 missing wage values using a wage equation. 